\title{
Social Discrimination As A Barrier For The Treatment Of Chronic Diseases In Venezuelan Migrants Of Peru
}

\author{
Carolina Delgado-Flores \\ Instituto de Evaluación de Tecnología en Salud e Investigación \\ Oscar Soto Cutrie \\ Universidad de San Martin de Porres Facultad de Medicina Humana \\ Wendy Nieto ( $\square$ wendy_nieto22@hotmail.com ) \\ Universidad Peruana Cayetano Heredia https://orcid.org/0000-0001-8012-1520
}

\section{Research article}

Keywords: Social Discrimination, Barrier For The Treatment Of Chronic Diseases, Venezuelan, Migrants Of Peru

Posted Date: May 29th, 2020

DOI: https://doi.org/10.21203/rs.3.rs-30848/v1

License: (a) (i) This work is licensed under a Creative Commons Attribution 4.0 International License. Read Full License 


\section{Abstract}

Objective: To determine the association between discrimination and treatment of chronic diseases in Venezuelan emigrants.

Methodology: Cross-sectional study, secondary analysis of the database of the "Survey directed at the Venezuelan population residing in the country" (ENPOVE), carried out in Peru in 2018. To evaluate the main association, we used a regression model of poisson, by adjusting the effect of the multistage sample using the svy command, and obtaining prevalence ratios (RP) with their respective confidence intervals $(95 \% \mathrm{Cl})$.

Results: A population of 865 Venezuelans ( $58.2 \%$ women, mean age: $36.6 \pm 0.7$ years) were evaluated, in which $54.8 \%$ reported having felt discriminated against for being Venezuelan and $89.2 \%$ reported not receiving treatment for their chronic disease. A statistically significant association was found between having been discriminated for being Venezuelan and having received treatment for chronic diseases, in the bivariate model (RPc: $0.38 ; 95 \% \mathrm{Cl}: 0.20-0.73$ ) and the adjusted model (RPa: $0.49 ; 95 \% \mathrm{Cl}: 0.25-0.97)$.

Conclusion: Our study found that having felt discriminated against decreases the prevalence of receiving treatment for chronic diseases by approximately $50 \%$ compared to those who did not report having been discriminated against. Future studies are necessary to evaluate the consistency of the results, with a larger population of Venezuelans residing in Peru.

\section{Introduction}

Venezuela is a country that is going through a marked economic and political crisis since 2013 (1), which has led the country to continued high economic inflation (2), forcing to emigrate to Latin American neighboring countries, being Peru the second with most Venezuelan migrants to date (3).

Until 2019, Peru was home to more than 860,000 Venezuelans, being only below Colombia in number of immigrants from Venezuela. (3).

This immigrations of Venezuelans has mainly led to a slowdown in the increasing trend of the average salary and a decrease in the labor supply in the Peruvian market, affecting above all the most vulnerable sectors (4), and so generating discomfort in the Peruvian population which probably triggers multiple attitudes of discrimination and disgust against Venezuelans.

Discrimination is defined as unequal and differential treatment towards a person or a group of people in the different areas of social life; this being an act that hinders and limits access to the right of all those affected (5).

Studies have shown that social discrimination is a frequent act during these migratory phenomena, reporting discrimination frequencies in migrants of $33.2 \%(6)$.

Social discrimination can affect the mental health of the immigrant, it can create a feeling of insecurity in the destination country and also a feeling of exclusion (7). Social discrimination could create an additional barrier in the access to national institutes, mainly the health ones (8), due to the fear of suffering discrimination acts that could be translated into medical malpractice.

We carry out the present study with the objective of determining the association between discrimination and access to treatment of chronical diseases in Venezuelan migrants. This study could contribute for the implementation of national agencies responsible for protecting this vulnerable group, regulation of sanctioning rules for acts of discrimination, and generation of policies that promote the rights of migrants within Peru.

\section{Methodology}

\section{Study design}

Transversal analytic study. Secondary analysis of the database in "Encuesta dirigida a la población venezolana que reside en el país ENPOVE", realized in 2018 by the Peruvian National Institute of Statistics and Informatics (9), which methodology has been previously reported (10).

\section{Study population, samples and selection criteria}

Page 2/13 
Study population by ENPOVE was made up of venezuelan immigrants living in the urban areas of the capitals of the departments of Tumbes, La Libertad, Arequipa, Cusco, Lima, and the constitutional province of Callao, because they were the cities that concentrated $85 \%$ of the Venezuelan population residing in Peru.

A multi-stage sampling was carried out, using a block at first instance as a sampling unit, and at second instance the households. Obtaining a sample of 3611 blocks, with 3697 houses and 9847 people interviewed.

Only immigrants who report having had any type of chronic disease and who were older than 18 years were included in the present study, evaluating a total of 865 Venezuelans.

\section{Procedure}

The ENPOVE 2018 was executed on November - December 2018, with the objective of providing data on the situation of the Venezuelan population residing in Peru; for the formulation, evaluation and monitoring of policies, plans, programs or projects directed at this population.

This survey was structured in eight topics: dwelling and home characteristics, house resident characteristics, migratory situation, health, education, job and earnings, discrimination, and gender and victimization. Although for the present secondary analysis topics related to characteristics of the residents, migratory situation, health, job, and discrimination were used.

\section{Outcome: Treatment of chronic disease}

The variable treatment of chronic disease was evaluated by the self-report of the interviewed with the following question: Do you receive treatment in Peru for the chronic illness or discomfort that you present? Which had three response options: 1) yes, with the necessary frequency, 2) yes, but without the necessary frequency, 3) do not receive treatment. For the present study the variable was categorized (do receive and do not receive treatment), considering just the ones who reported to receive treatment with the necessary frequency like "do receive treatment".

\section{Exposition: Discrimination}

The variable discrimination was evaluated with the question "have you ever felt discriminated for being a Venezuelan since you came to Peru?", and categorized in non-discriminated and discriminated.

\section{Others variables}

Including other variables as gender (male and female), age (categorized in thirds), marital state (single and married/widower), education levels (no studies or primary, secondary, and high studies), current job (unemployed and employed),totally economic income (soles), residency department (Arequipa, Lima y Callao, Cusco, La Libertad and Tumbes), presence of disability (without disability and with a disability), type of chronic disease (high blood pressure, bronchial asthma, diabetes mellitus, and others), migratory situation (legal and illegal or in the process of legalization), and health insurance (Without health insurance and with health insurance).

\section{Statistical analysis}

Data analysis was performed using the Stata v.15 statistical package. An adjustment was made for the effect of multi-stage sampling using the "svy" command, taking the block as the sampling unit and the city of residence as the stratum. Subsequently, a descriptive analysis of the data was performed using absolute and relative frequencies, and the comparison of the proportions and means using the chi-square and student's t tests.

For the evaluation of the association of interest between discrimination and the treatment of chronic disease, a poisson regression model was used. In this way, crude prevalence ratios (RPc) and adjusted under potential confounders (RPa), with their respective $95 \%$ confidence intervals $(95 \% \mathrm{Cl})$ were obtained. $\mathrm{P}<0.005$ was taken into account as significant.

\section{Results}

From a total population of 9,852 Venezuelan migrants, 1,956 interviewees were excluded for being under the age of 18 , and 7,031 for not having reported having a chronic disease. 
A population of 865 Venezuelans ( $58.2 \%$ women, mean age: $36.6 \pm 0.7$ years) was evaluated, of which $55.1 \%$ were married / widowed, $58.5 \%$ had a higher educational level, $76.2 \%$ currently had a job, $92.7 \%$ did not have health insurance, and $54.8 \%$ reported having felt discriminated against for being Venezuelan within Peru. (Table 1) 
Table 1

Characteristics of the population of Venezuelan migrants with chronic diseases $(\mathrm{N}=865)$

\begin{tabular}{|c|c|}
\hline Variables & $\mathbf{N}(\%)$ \\
\hline \multicolumn{2}{|l|}{ Sex } \\
\hline Men & $431(41.82)$ \\
\hline Women & $606(58.18)$ \\
\hline \multicolumn{2}{|l|}{ Age (years) } \\
\hline 18 a 26 & $233(25.60)$ \\
\hline 27 a 34 & $217(26.34)$ \\
\hline 35 a 93 & $415(48.07)$ \\
\hline \multicolumn{2}{|l|}{ Marital status } \\
\hline Single & $426(44.88)$ \\
\hline Married / Widowed & $486(55.12)$ \\
\hline \multicolumn{2}{|l|}{ Education level } \\
\hline Without studies or Primary & $232(9.98)$ \\
\hline High school & $260(31.49)$ \\
\hline Higher education & $520(58.52)$ \\
\hline \multicolumn{2}{|l|}{ Current job } \\
\hline Unemployed & $321(23.79)$ \\
\hline With employment & $672(76.21)$ \\
\hline Total economic income (soles) & $897.39 \pm 33.63$ \\
\hline \multicolumn{2}{|l|}{ Residence department } \\
\hline Arequipa & $153(1.12)$ \\
\hline Lima and Callao & $585(96.38)$ \\
\hline Cusco & $69(0.27)$ \\
\hline La Libertad & $163(2.02)$ \\
\hline Tumbes & $67(0.22)$ \\
\hline \multicolumn{2}{|l|}{ Disability } \\
\hline No disability & $974(94.21)$ \\
\hline With disability & $63(5.79)$ \\
\hline \multicolumn{2}{|l|}{ Chronic diseases } \\
\hline Hypertension & $176(19.29)$ \\
\hline Asthma & $60(5.18)$ \\
\hline Diabetes & $383(34.79)$ \\
\hline Other & $418(40.75)$ \\
\hline \multicolumn{2}{|l|}{ Migratory situation } \\
\hline Legal & $641(55.94)$ \\
\hline
\end{tabular}

Page 5/13 


\begin{tabular}{|c|c|}
\hline Variables & $\mathbf{N}(\%)$ \\
\hline Illegal or in process of legalization & $396(44.06)$ \\
\hline Health insurance & \\
\hline Without health insurance & $940(92.71)$ \\
\hline With health insurance & $97(7.29)$ \\
\hline Social discrimination & $525(45.21)$ \\
\hline Non-discriminated & $468(54.79)$ \\
\hline Discriminated & $762(89.23)$ \\
\hline Receive treatment for chronic disease & $103(10.77)$ \\
\hline Not receive treatment & \\
\hline Receive treatmet &
\end{tabular}

Among the chronic diseases reported, $34.8 \%, 19.3 \%$ and $5.2 \%$ reported having diabetes mellitus, high blood pressure, and bronchial asthma, respectively. (Table 1 )

It was reported that $89.2 \%$ did not receive treatment for their chronic disease, which was associated with sex $(p=0.016)$, age $(p<$ $0.001)$, employment status $(p=0.008)$, immigration status $(p=0.014)$, health insurance $(p=0.003)$, and having been discriminated against $(p=0.002)$. (Table 2$)$ 
Table 2

Factors associated with receiving treatment for chronic disease in Venezuelan migrants.

\begin{tabular}{|c|c|c|c|}
\hline \multirow[t]{3}{*}{ Variables } & \multicolumn{2}{|c|}{ Receive treatment for chronic disease } & \multirow[t]{3}{*}{ p } \\
\hline & Not receive & Receive & \\
\hline & $N(\%)$ & $\mathrm{N}(\%)$ & \\
\hline \multicolumn{3}{|l|}{ Sex } & \multirow[t]{3}{*}{0.016} \\
\hline Men & $309(93.21)$ & $27(6.79)$ & \\
\hline Women & $453(86.37)$ & $76(13.63)$ & \\
\hline \multicolumn{3}{|l|}{ Age (years) } & \multirow[t]{4}{*}{$<0.001$} \\
\hline 18 a 26 & $217(95.90)$ & $16(4.10)$ & \\
\hline 27 a 34 & $202(92.42)$ & $15(7.58)$ & \\
\hline 35 a 93 & $343(83.92)$ & $72(16.08)$ & \\
\hline \multicolumn{3}{|l|}{ Marital status } & \multirow[t]{3}{*}{0.334} \\
\hline Single & $329(87.68)$ & $51(12.32)$ & \\
\hline Married / Widowed & $433(90.49)$ & $52(9.51)$ & \\
\hline \multicolumn{3}{|l|}{ Education level } & \multirow[t]{4}{*}{0.084} \\
\hline Without studies or Primary & $83(82.12)$ & $19(17.88)$ & \\
\hline High school & $221(92.82)$ & $22(7.18)$ & \\
\hline Higher education & $458(88.51)$ & $62(11.49)$ & \\
\hline \multicolumn{3}{|l|}{ Current job } & \multirow[t]{3}{*}{0.008} \\
\hline Unemployed & $168(82.98)$ & $36(17.02)$ & \\
\hline With employment & $594(91.18)$ & $67(8.82)$ & \\
\hline Total economic income (soles) & $905.39 \pm 34.67$ & $831.11 \pm 125.23$ & 0.570 \\
\hline \multicolumn{3}{|l|}{ Disability } & \multirow[t]{3}{*}{0.090} \\
\hline No disability & $722(89.93)$ & $96(10.07)$ & \\
\hline With disability & $40(77.87)$ & $7(22.13)$ & \\
\hline \multicolumn{3}{|l|}{ Migratory situation } & \multirow[t]{3}{*}{0.014} \\
\hline Legal & $475(92.26)$ & $42(7.74)$ & \\
\hline Illegal or in process of legalization & $287(85.38)$ & $61(14.62)$ & \\
\hline \multicolumn{3}{|l|}{ Health insurance } & \multirow[t]{3}{*}{0.003} \\
\hline Without health insurance & 709 (90.37) & $82(9.63)$ & \\
\hline With health insurance & $53(74.69)$ & $21(25.31)$ & \\
\hline \multicolumn{3}{|l|}{ Social discrimination } & \multirow[t]{3}{*}{0.002} \\
\hline Non-discriminated & $370(83.70)$ & $68(16.30)$ & \\
\hline Discriminated & $392(93.79)$ & $35(6.21)$ & \\
\hline
\end{tabular}

Regarding the main association of interest, a statistically significant association was observed between having been discriminated against for being Venezuelan in Peru and having received treatment for chronic disease, both in the bivariate model (RPc: 0.38 ; $95 \%$ Cl: $0.20-0.73$ ) as in the multiple (RPa: 0.49; 95\% Cl: 0.25-0.97). (Table 3) 
Table 3

Association between discrimination and the receiving pharmacological treatment in Venezuelan migrants, in a regression model.

\begin{tabular}{|c|c|c|c|c|c|c|}
\hline \multirow[t]{2}{*}{ Variables } & \multicolumn{3}{|c|}{ Bivariate analysis } & \multicolumn{3}{|c|}{ Multiple regression } \\
\hline & RPc & IC 95\% & $\mathbf{p}$ & $\mathrm{RPa}$ & IC 95\% & $\mathbf{p}$ \\
\hline \multicolumn{7}{|l|}{ Sex } \\
\hline Men & Ref. & & & Ref. & & \\
\hline Women & 2.01 & $1.12-3.60$ & 0.02 & 1.50 & $0.81-2.79$ & 0.195 \\
\hline \multicolumn{7}{|l|}{ Age (years) } \\
\hline 18 a 26 & Ref. & & & Ref. & & \\
\hline 27 a 34 & 1.85 & $0.76-4.52$ & 0.178 & 1.91 & $0.79-4.59$ & 0.150 \\
\hline 35 a 93 & 3.92 & $1.73-8.88$ & 0.001 & 3.24 & $1.45-7.20$ & 0.004 \\
\hline \multicolumn{7}{|l|}{ Marital status } \\
\hline Single & Ref. & & & Ref. & & \\
\hline Married / Widowed & 0.77 & $0.46-1.31$ & 0.335 & 0.78 & $0.45-1.36$ & 0.384 \\
\hline \multicolumn{7}{|l|}{ Education level } \\
\hline Without studies or Primary & Ref. & & & Ref. & & \\
\hline High school & 0.40 & $0.18-0.91$ & 0.028 & 0.61 & $0.27-1.37$ & 0.230 \\
\hline Higher education & 0.64 & $0.35-1.18$ & 0.152 & 1.01 & $0.53-1.92$ & 0.979 \\
\hline \multicolumn{7}{|l|}{ Current job } \\
\hline Unemployed & Ref. & & & Ref. & & \\
\hline With employment & 0.52 & $0.32-0.84$ & 0.008 & 0.78 & $0.44-1.39$ & 0.396 \\
\hline Total economic income (soles) & 1.00 & $1.00-1.00$ & 0.612 & 1.00 & $1.00-1.00$ & 0.290 \\
\hline \multicolumn{7}{|l|}{ Disability } \\
\hline No disability & Ref. & & & Ref. & & \\
\hline With disability & 2.20 & $0.91-5.29$ & 0.079 & 1.28 & $0.66-2.50$ & 0.467 \\
\hline \multicolumn{7}{|l|}{ Migratory situation } \\
\hline Legal & Ref. & & & Ref. & & \\
\hline Illegal or in process of legalization & 1.89 & $1.13-3.16$ & 0.016 & 1.49 & $0.88-2.52$ & 0.140 \\
\hline \multicolumn{7}{|l|}{ Health insurance } \\
\hline Without health insurance & Ref. & & & Ref. & & \\
\hline With health insurance & 2.63 & $1.41-4.89$ & 0.002 & 1.94 & $1.05-3.56$ & 0.034 \\
\hline \multicolumn{7}{|l|}{ Social discrimination } \\
\hline Non-discriminated & Ref. & & & Ref. & & \\
\hline Discriminated & 0.38 & $0.20-0.73$ & 0.004 & 0.49 & $0.25-0.97$ & 0.039 \\
\hline
\end{tabular}

Likewise, a statistically significant association was found between receiving pharmacological treatment of chronic disease with being a woman (RPc: $2.01 ; 95 \%$ Cl: 1.12-3.60), having a secondary education level (RPc: 0.40; 95\% Cl: 0.18-0.91), having a job (RPc: 0.52; $95 \% \mathrm{Cl}: 0.32-0.84$ ), and being in the country as illegal or being in a legalization process (RPc: $1.89 ; 95 \% \mathrm{Cl}: 1.13-3.16)$, which lost significance in the multiple regression model. However, having an age between 35 to 93 years (RPc: 3.92, 95\% Cl: 1.73-8.88; RPa: 
$3.24,95 \% \mathrm{Cl}: 1.45-7.20)$ and having health insurance (RPc: $2.63,95 \% \mathrm{Cl}: 1.41-4.89 ; \mathrm{RPa}: 1.94,95 \% \mathrm{Cl}: 1.05-3.56)$ were significantly associated with the outcome of receiving treatment for chronic disease, both in bivariate and multiple regression analyzes. (Table 3 )

\section{Discussion \\ Descriptive results}

Of the total population surveyed by ENPOVE ( $\mathrm{N}=9852)$ only 865 participants reported having a chronic disease, representing less than $10 \%$ of the population. This low proportion of patients with chronic diseases is probably because, during the migration phenomenon, migrants tend to be in good health since this allows them to achieve their goals in the destination country (11), so it would be expected that the population with some previously diagnosed pathology would refrain from migrating. However, the collapse of medical care in Venezuela can also lead to the search of health systems abroad, that would allow them to control their health needs, such as reproductive health, contagious diseases, chronic diseases, mental disorders, among others (12).

The most frequent chronic diseases reported by Venezuelans are high blood pressure and diabetes mellitus. This agrees with the WHO/PAHO reports where high blood pressure and diabetes mellitus are the most prevalent chronic diseases in the world, including Latin America and the Caribbean $(13,14)$.

Approximately $97 \%$ of the migrant population was concentrated in Lima and Callao, probably due to the globalization and urbanization characteristic of the capital (15), since it has better business and investment opportunities for migrants compared to other cities in the country.

\section{Treatment of chronic disease}

In our study, $11 \%$ of Venezuelan migrants received treatment for their chronic disease. Similar figures have been reported in a study in Chile (16), where $13 \%$ of migrants received some treatment for their medical condition.

This interruption of treatment may be originated during the displacement or migration phenomena (17), requiring health care and access to permanent treatment for their control and management of complications at their final destination (18). However, in the absence of this treatment, the chronic disease of migrants progresses and worsens (19), leading to a decrease in the quality of life of the migrant and an increase in the health care expenditure in the local health sector (20).

In many cases this lack of treatment is due to irregular documentation, which limits the migrant free access to the health service, paying for their health needs with their own money (16). This added to a greater probability of being in a bad economic situation (11, 21 ), motivates them to prioritize spending on other basic needs, leaving aside their medical care. However, in our study almost $56 \%$ of migrants had valid immigration documents, so there are probably other possible factors that cause this lack of treatment. Some studies mention that behavioral and idiosyncratic factors (22-24), such as discrimination, lack of support, ignorance of the destination country's health system and others, make migrants to not demand health services (25).

\section{Social discrimination}

More than $50 \%$ of the surveyed migrants claimed to have been victims of discriminatory acts. These figures are similar to those reported in previous studies carried out on a population of migrants in Korea (26) and the Netherlands (27), where 50\% and 55\% of migrants, respectively, reported being victims of discrimination.

It has been reported that it is common to detect discriminatory attitudes during a migratory phenomenon, both by the personnel of the health facility and the general population, as a result of indifference to the circumstances and conditions for which migration occurred (28). This event is probably due to the fact that there is a change in the behavior of the migrant themselve, being more permissive since they are in a country different from their own, which contributes to an imbalance in their biopsychosocial well-being, making them a vulnerable population for discrimination (29). Likewise, these discriminatory acts become more frequent because they are allowed by the migrants themselves for fear of the authorities, employers and society in general (30), which may lead to this discriminatory act being normalized and even underestimated in the country.

This behavior of rejection or discrimination against migrants is the product of a society fearful of the negative burden on the country's economy, the risk of substitution of jobs for citizens and, above all, the reduction of their wages. (11). However, in Peru, according to 
statistics from the National Institute of Statistics and Informatics (INEI), the economically active migrant population is less than $1 \%$ of the total Peruvian labor market. This means that migrants could not have any negative effect on the local economy, and even a study maintains that the migratory phenomenon has a positive long-term effect on the economy of the destination country (4).

Discrimination is a stressful factor for the migrant, which could generate negative feelings, affect health, promoting unhealthy behavior such as abandonment of pharmacological treatment, and it can also lead to physiological changes (neuroendocrine, autonomic and immune) (31). Being able to modify the course of chronic diseases, even producing acute episodes of it (32).

Even if, in Peru, the law $N^{\circ} 28867$ (33) of the penal code establishes the sanctions against discriminatory acts, many of these acts are not reported, denounced or are simply underestimated by the affected population (29). For this reason, it is necessary that in a migratory phenomenon the national authorities of the receptor country consider the development of preventive strategies for discrimination, such as establishing a communicative campaign to inform the benefits of a systematic migration process and the corrective strategies against xenophobia. Likewise, they could implement organizations responsible for looking after this vulnerable population, being able to collaborate with national and international organizations to provide aid to migrants.

\section{Other associated factors}

$7.3 \%$ of the migrant population has health insurance, and the prevalence of receiving treatment for chronic diseases in them increases to $94 \%$ compared to uninsured migrants.

Possible causes that lead migrants to not process their health insurance include lack of knowledge about the policies that benefit them, discrimination, immigration irregularity, because migrants with illegal status fear that health service providers will report them to the authorities (11); the different disease patterns, different access behaviors to the health system, economic and social variability, and the provision of health insurance coverage (16).

However, the "International Convention on the Protection of the Rights of All Migrant Workers and Members of Their Families" is an international instrument, which objective is to protect the migrant rights. It details that documented or undocumented migrants have the right to access only emergency medical care (11). Similarly, in Peru, in 2019, an Emergency Decree No. 017-2019 was issued which establishes that access to Comprehensive Health Insurance (SIS, for its initials in Spanish) would have coverage for all citizens of the country. This included Venezuelan residents, who work, got married, or have an immigration card. It should be noted that this affiliation to the SIS guarantees beneficiaries free coverage of the Essential Health Insurance Plan - PEAS (34).

On the other hand, the prevalence of access to long-term drug treatment among migrants aged 35-93 increased substantially (224\%) compared to migrants aged 18-26. This result may be due to higher prevalence of chronic conditions at that age, which requires greater disease control and adherence to drug treatments (35). In contrast to the young age group from 18 to 26 years old, who prioritize work, exposing themselves to occupational diseases and unhealthy environments, or risking their own safety (36), and so neglecting their health care.

\section{Limitations And Strengths}

This study may have limitations that must be considered. First, a low percentage of participants with chronic diseases was observed, compared to other populations, probably because the evaluation of chronic diseases of Venezuelan migrants was done through selfreport, and there may be an underestimation of the data in case the participant has a chronic disease, but has not gone to a health center where they are diagnosed. Second, social discrimination is a variable that is self-perceived by the participants, there are probably immigrants who consider an act that does not fall within the definition of social discrimination as discrimination, and may overestimate the results.

Despite this, there is little evidence about migratory phenomena and their consequences on migrants health, being this study one of the few that has taken a population of Venezuelans living in more than one department of Peru. Likewise, the present study evidences a common social problem that needs to be addressed not only because of its consequences on the mental health of the migrant but also due to its interference in health access.

\section{Conclusion}

Page $10 / 13$ 
In the study population, the prevalence of receiving treatment for chronic diseases in discriminated Venezuelan migrants decreased compared to the non-discriminated, being it statistically significant. New studies with a larger population of Venezuelan migrants residing in Peru are necessary to evaluate the consistency of the results. Likewise, it is necessary to establish preventive strategies and protective institutions for this vulnerable population that are the migrants.

\section{Declarations}

\section{Ethics approval and consent to participate}

The present study is secondary analysis of ENPOVE. ENPOVE participants were previously informed of the objectives and implications of the survey. Likewise, a codification of both the surveyed individual and the dwelling, block, and home was performed.

\section{Consent for publication}

Does not apply to this study

Competing interests

The authors have no conflict of interest to declare.

\section{Availability of data and materials}

The data of this study are available to the web site of "National Institute of Statistics and Informatics of Peru" (http://iinei.inei.gob.pe/microdatos/)

\section{Funding}

The present study has been self-financed by the authors.

\section{Authors' contribution}

OSC and WNG conception or design of the work. CDF and analysis and interpretation of data for the work. All of the authors drafting the work or revising it critically for important intellectual content, and final approval of the version to be published. The authors agreement to be accountable for all aspects of the work in ensuring that questions related to the accuracy or integrity of any part of the work are appropriately investigated and resolved.

\section{Acknowledgements}

Does not apply to this study

\section{References}

1. El Dinero [Web Page]. Venezuel: El Diario; 2018 [cited 5 oct 2019] Consecuencias del modelo económico de Venezuela [Available from: https://www.eldinero.com.do/56231/consecuencias-del-modelo-economico-venezolano/.

2. Roa AC. Sistema de salud en Venezuela: ¿un paciente sin remedio? Cadernos de Saúde Pública. 2018;34.

3. Agencia de la ONU para los refugiados [Web Page]. Nueva

Agencia de la ONU para los refugiados [Web Page]. Nueva. York: UNHCR ACNUR; 2018 [cited 5 oct 2019] Situación en venezuela [Available from: https://www.acnur.org/situacion-en-venezuela.html.

4. Oviedo JV. Efectos de corto plazo de la inmigración venezolana en el Perú. Pensamiento Crítico.23(2):73-96. 
5. Ministerio de Empleo y Seguridad Social. Informe sobre discriminación de personas migrantes y refugiadas en España. In: Refugiado, CEdAa, editors. España: CEAR; 2016.

6. Ministerio de trabajo myssl. Informe sobre la evolución de los incidentes relacionados con los delitos de odio en España. In: Secretaría de estado de seguridad. editor. España: MITRAMISS; 2018.

7. Ochoa Mangado E, Vicente Muelas N, Lozano Suárez M. Síndromes depresivos en la población inmigrante. Revista Clínica Española. 2005;205(3):116-8.

8. Organización Mundial de la Salud [Internet]

Organización Mundial de la Salud [Internet]. Suiza: OMS. 2017 [citado 5 oct 2019] Poner fin a la discriminación en los centros de atención sanitaria [.

9. Instituto Nacional de Estadística e Informática. Ficha técnica ENPOVE 2018. In: Dirección nacional de demografía e indicadores sociales. editor. Lima: INEl; 2018.

10. Instituto Nacional de Estadística e Informática. Condiciones de vida de la población venezolana que reside en Perú: Resultados de la "Encuesta dirigida a la población venezolana que reside en el país" ENPOVE 2018. In: INEI, editor. Perú: INEl; 2019.

11. Organización de las Naciones Unidas. Estado de la población mundial 2006. In: UNFPA, editor. Nueva York: Fondo de Población de las Naciones Unidas; 2006.

12. ACNUR [Web Page]

ACNUR [Web Page]. Suiza: ACNUR. 2019 [cited 5 nov 2019] Las amenazas de muerte y las enfermedades obligan a más venezolanos a huir [Available from: https://www.acnur.org/noticias/noticia/2019/5/5ce410ea4/las-amenazas-de-muerte-y-lasenfermedades-obligan-a-mas-venezolanos-a-huir.html.

13. Organización Panamericana de la Salud [Web Page]. USA: OPS; 2017 [cited 31 march 2020] Día Mundial de la Hipertensión 2017: Conoce tus números. [Available from: https://www.paho.org/hq/index.php? option=com_content\&view=article\&id=13257:dia-mundial-de-la-hipertension-2017-conoce-tus-numeros\&ltemid=42345\&lang=es .

14. Organización Mundial de la Salud. Informe mundial sobre la diabetes. In: Catalogación por la Biblioteca de la OMS. editor. Suiza: OMS; 2016.

15. El Montero [Web Page]. Perú: Carpio; 2018 [cited 31 march 2020] Lima: centro de inmigración de Sudamérica. [Available from: https://elmontonero.pe/columnas/lima-centro-de-inmigracion-de-sudamerica.

16. Cabieses B, Bernales M, McIntyre AM. La migración internacional como determinante social de la salud en Chile: evidencia y propuestas para políticas públicas. 2017.

17. Pavli A, Maltezou H. Health problems of newly arrived migrants and refugees in Europe. Journal of travel medicine. 2017;24(4).

18. World Health Organnization [Web Page]. Ginebra: WHO [cited 29 oct 2019] Migration and health: key issues Migration and Health [Available from: http://www.euro.who.int/en/health-topics/health-determinants/migration-and-health/migrant-health-in-theeuropean-region/migration-and-health-key-issues\#292932.

19. Williams DR, Mohammed SA. Discrimination and racial disparities in health: evidence and needed research. J Behav Med. 2009;32(1):20-47.

20. Organización Mundial de la Salud [Web Page] Organización Mundial de la Salud [Web Page]. Ginebra: OMS. 2003 [cited 29 oct 2019] El incumplimiento del tratamiento prescrito para las enfermedades crónicas es un problema mundial de gran envergadura [Available from: https://www.who.int/mediacentre/news/releases/2003/pr54/es/.

21. Calavita K. Gender, Migration, and Law: Crossing Borders and Bridging Disciplines. Int Migrat Rev. 2006;40(1):104-32.

22. Ortega AN, Fang H, Perez VH, Rizzo JA, Carter-Pokras 0 , Wallace SP, et al. Health care access, use of services, and experiences among undocumented Mexicans and other Latinos. Arch Intern Med. 2007;167(21):2354-60.

23. Ku L, Matani S. Left out: immigrants' access to health care and insurance. Health Aff. 2001;20(1):247-56.

24. Leclere FB, Jensen L, Biddlecom AE. Health care utilization, family context, and adaptation among immigrants to the United States. Journal of health social behavior. 1994;35(4):370-84.

25. Gresenz CR, Rogowski J, Escarce JJ. Community demographics and access to health care among U.S. Hispanics. Health services research. 2009;44(5 Pt 1):1542-62. 
26. Kim Y, Son I, Wie D, Muntaner C, Kim H, Kim S-S. Don't ask for fair treatment? A gender analysis of ethnic discrimination, response to discrimination, and self-rated health among marriage migrants in South Korea. International Journal for Equity in Health. 2016;15(1):112.

27. Andriessen I, Fernee H, Wittebrood K, [Web, Page],. Netherlands: 2014 [cited 31 march 2020] Perceived discrimination in the Netherlands. [Available from:

https://www.scp.nl/english/Publications/Publications_by_year/Publications_2014/Perceived_discrimination_in_the_Netherlands.

28. Concha NPL. De la alterisación a la discriminación en un sistema público de salud en crisis: conflictos interétnicos a propósito de la inmigración sudamericana en Chile. Revista de Ciencias Sociales (Cl). 2012(28):19-38.

29. Moya J, Uribe M. Migración y salud en México: Una aproximación a las perspectivas de investigación, 1996-2006. Organización Panamericana de la Salud. 2007.

30. Organización Internacional para las migraciones [Internet]. Informe regional sobre determinantes de la salud de las personas migrantes retornadas o en tránsito y sus familias en centroamérica. In: Dirección General de Migración y Extranjería GdES, Guatemala, Honduras y Nicaragua,, editor. El Salvador: Ministerio de Salud, Gobiernos de El Salvador, Guatemala, Honduras y Nicaragua.;; 2015.

31. Cohen S, Kessler RC, Gordon LU. Strategies for measuring stress in studies of psychiatric and physical disorders. In: Measuring stress: A guide for health and social scientists. New York: Oxford University Press; 1995. pp. 3-26.

32. Bhattacharyya MR, Steptoe A. Emotional triggers of acute coronary syndromes: strength of evidence, biological processes, and clinical implications. Prog Cardiovasc Dis. 2007;49(5):353-65.

33. Congreso de la república. Ley № 28867. Perú: Congreso de la república; 2006.

34. El Peruano [Web Page]. Perú: 2019 [cited 31 march 2020] Decreto de urgencia que establece medidas para la cobertura universal de salud. [Available from: https://busquedas.elperuano.pe/normaslegales/decreto-de-urgencia-que-establece-medidas-para-lacobertura-decreto-de-urgencia-n-017-2019-1831446-1/.

35. Arriagada Luco C, Cortinez JM. Santiago, lugar de encuentro: transformaciones y propuestas. 2015.

36. Moreno MB, Klijn TP. Atención en salud para migrantes: un desafío ético. Revista Brasileira de Enfermagem. 2011;64:587-91. 